\section{SINGIDUNUM Y VERSITA}

SINGIDUNUM JOURNAL 2013, 10 (2): 32-39

ISSN 2217-8090

UDK 005.6:338.487

DOI: $10.5937 /$ sjas $10-4263$

Original paper/Originalni naučni rad

\title{
STRUCTURAL-DIMENSIONAL CONCEPT OF TOURISM SERVICE QUALITY
}

\author{
Vukan P. Vujović1, ${ }^{1 *}$ \\ ${ }^{1}$ Singidunum University, PhD student, \\ 32 Danijelova Street, Belgrade, Serbia
}

\begin{abstract}
:
The difficulties of delivering a consistently satisfactory quality of tourism services emerge as a result of the discrepancies between the productive structures and corresponding dimensional features of delivering values during their cycle of consumption. Organizational enterprise system is the primary responsible for the above mentioned phenomenon, and it consists of production (working) units and departments in charge of quality management as well as control and monitoring of the production processes, that is, the flow of delivery. This paper discusses the current models of structural complexity, dimensional observations of quality as well as the phases of user participation throughout the life cycle of tourism services. The possibility of identifying several typical levels in the complex tourism product provides the groundwork for a more meaningful comparison between "projected and actual quality", as well as achieving greater organizational performances in the domain of market-delivered value of the resulting service. The main objective of this paper is to provide a theoretical basis for the implementation of deeper organizational and functional analysis models and continuous monitoring of the achieved quality. The effects of such systematic approach would be manifested to the ultimate degree of fulfillment of expectations and the overall customer or user satisfaction with tourism service.
\end{abstract}

\section{Key words:}

tourism services, structural concept, dimensional models, quality.

\section{INTRODUCTION}

Under the current circumstances, the achievement of the expected market quality of services, building of market image, creation of a potential service brand, marketing performance and strategic positioning among competitors based on self-or corporate-integrating market share - has become a very difficult and systematic task. This particularly applies to the aspect of the finally realized or resulting (i.e. final) quality, which stems from a thoroughly planned, organized, coordinated and supervised process of market value creation. It simply requires almost irreproachable functionality of the complete production process and highly professional responsibility of the involved organizational staff.

The services represent the core of economic activity in any society. The service sector already accounts for $60-70 \%$ of GDP in most of the developed countries, and thus significantly exceeds factory production and agriculture. Such a high percentage is transferred to a global level, as it were, the developed market economies of today are actually "service economic systems" - with significant participation by the service sector (Popesku, 2009).

A modern market in which travel agents are fighting for their share in the market is characterized by maturity, which is manifested in a growing 
demand for the so-called authentic tourist services. In order to achieve that, the above mentioned subjects should be directed towards strategies based on experience in which the common authenticity and delivery of the value rich tourism services is perceived as real and grounded psychological and emotional categories (Cooper and Hall, 2008).

Faced with more intensive growth and spatial expansion of tourism activities, the service organizations were sent to a more sophisticated, more user educated and more demanding market segments. Their philosophy of life imbued with the expressed desire for individuality and growing needs of the specificity of service, coupled with the ideological, socio-economic and cultural tradition leads to the complexity of the process of delivery of the expected market value (Čerović, 2009).

As for the above given reasons and in order to improve the efficiency of market operations, management services and departments of service companies resort to various approaches (i.e. accesses) to the issues of generated or achieved quality of travel service, using the settings of contrived management production systems, distribution and delivery (Zeithaml and Bitner, 2003). Most of these approaches are based on determining the correlation and causality of factors of production and delivery, detection and removal of the defects of manufacturing-service process (both the internal and external organizational resources) and establishing the models for qualitative and/or quantitative measurement and analysis of tourism service quality.

The process of providing services based on the strategic planning and marketing-promotional activities of service entities hides a whole host of organizational decisions, solutions and standardized proceedings associated with the elements of organizational functionality and creating a unique organizational culture (Segal-Horn, 1993). Due to its complexity and difficulties related to the ability to accurately perform monitoring and internal recording when it comes to the quality of market placements (of external), service value has not yet established a reliable criterion that would enable comparison between the effects or omissions in various stages of production and those in the appropriate stages of the delivering part of the process.

Therefore, it may rightly ask: "Is it, and how is it possible to indirectly connect the process of making the appropriate quality of tourism service to the process of delivery of the same, having perceived it in terms of failure made in the production cycle and accomplished placement on the tourism services market?". This question corresponds to the essential research issues, and also represents the subject of this work.

In order to successfully establish a quality system and maintain the desired level of production efficiency, it is necessary to more precisely align its structural components (starting from the lowest organizational and business unit), constantly enrich the process of production and delivery with the modern technology and achievements, and even be possible to stay "step ahead" compared to the current market competition.

The aim of this paper is to highlight the importance of systematic analysis and establish monitoring of emerging quality in meeting the organizational standards connected with the intense "floating" and "transforming" user requirements. While the task of the paper is to point to some of the structural and dimensional models that provide a clear insights into the complexity of a productional-service cycle and functioning of delivery system, and thus, reveal potential disadvantages of tourist service.

\section{STRUCTURAL FEATURES OF QUALITY}

The comparison of the structural features of quality raises the concept of the interconnection of products and services into a single system in terms of the processes of creation and placement of the total market value. Thereby, a new creation that combines both terms is generated by implying the introduction of a new term of consistent tourist product, which is the "tourist product".

The individual components of the tourism product have a tangible character and represent the basis or "foundation" of its structure. However, an authentic tourism product arises only in the presence of customers or users/visitors at the time of delivery, i.e. consumption of its intangible component, or "services"(Kosar and Rašeta, 2005).

Service components can represent a smaller or larger part of the total offer of tourism products. In this sense, it is possible to distinguish five categories of service mix offers which include the following: pure tangible products, tangible products with accompanying services, hybrid, major products with accompanying minor products or services and pure services (Kotler and Keller, 2012). 
The complex structure of the tourism product is presented using the example of the improved model or the so-called "Five level model" (Kotler and Keller, 2012), which includes the following:

1. Basic/essential elements or "core products": the expected basic benefits for the consumer, the design of physical characteristics;

2. Formal elements or "formal/tangible products": organizational concepts, compliance, standard levels of brand quality;

3. Extended elements or "improved/increased products": additional service facilities, location, services, behavior styles;

4. Specific elements or "extra product/constellation of values": recognition of the service brand/image, special "deluxe" benefits, and

5. Anticipating elements or "potential products": values embedded on the basis of the user's perception measurements, the vision of a future market brand.

Tourism services often involve the complete absence of tangible products, and if they are included, it is primarily important to understand the basic customer needs that are satisfied upon the very act of purchase (Zeitham and Bitner, 2003).

Apart from the tangible and intangible elements ("hard" and "soft" elements) the structure of the quality of tourism services depends on the following elements of the environmental and socio-cultural environment: resource utilization, environmental preservation, cultural impact, sustainability (Müller, 2000).
It is a necessary precondition for the establishment and improvement of production and delivering process regarding the organizational business assets. They are classified into two main groups according to their essential features: working capital and fixed capital.

The fixed capital assets enter the reproduction process and come out of it as a whole, in an unmodified form. Although they appear in the form of cash and in the form of certain rights and claims, their decisive form are material things (which is why they are, observed by the time, always gradually consumed). This value-transformation is also being transferred over time to the quality of delivered services. It represents the functional weakness of the service organization, but also a real threat to the users perception (Kosar, 2002).

On the other hand, it is typical of working capital assets to be spent during one reproductive (i.e. current) cycle by single use within the manufacturingservice process, thus changing their initial form and transferring their overall value to the new tourist product (service). The schemes of reproductive cycles in the case of working capital and fixed assets of service can be simplified by the following illustration (see Figure 1).

The concept of quality has multiple meanings. For the user, the quality of tourism services is what he buys from the organization and has the right value that he received for the money he gave. This is called market (external) approach of customeroriented definition. The second approach defines quality as the degree of compliance with the inter-

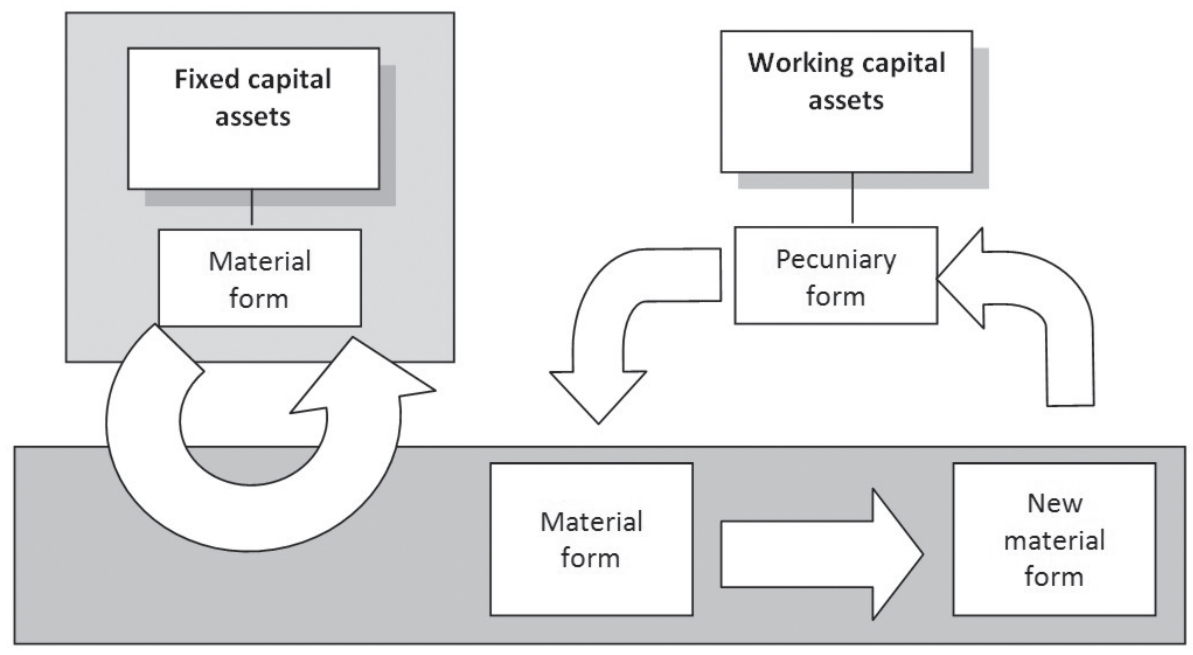

Figure 1. The preview of reproductive cycle of fixed and working capital assets

Adapted from the text: Kosar (2002, pp. 216-217) 
nal specifications, pointing mainly to the technical characteristics of the product. This is the so called manufactural (internal) approach to defining quality (Heleta, 2008).

The manufacturing dimension of reproduction process allows an interpretation in line with the classical economic determination, while the service dimension of reproduction process points to the absence of classical economic function, since it lacks the material product of service as a result of manufacturing-service process (Kosar, 2002).

However, the new approach sets the user of travel services to the forefront. According to it, the quality of service presents the degree of fulfillment of the following: requirements, expressed needs and expectations. Consequently, the user is the one who actually defines and confirms the service quality level. Since quality today means primarily the value for the customer, the only valid assessment of quality is the personal opinion of the service user (Seghezzi, 1992).

\section{DIMENSIONS OF TOURISM SERVICE QUALITY}

The basic distinction made in relation to the dimensions of service quality is the one between technical and functional quality. Technical quality places an emphasis on the results of the service process by posing the following question: WHAT does the customer receive as a final delivery?; while the functional quality explains the service delivery system by answering the question: HOW does a customer receive, use and experience tourism services? In other words, technical quality refers to what is available to the client upon completion of the interaction between the user supplier/employee, while the functional quality is the service delivery process. In addition to this, there is a third dimension of quality as the social (ethical) quality. This dimension refers to the quality of customer trust, and cannot be evaluated before, as well as after the provision of services (Ćosić, 2007).
The service organizations must endeavor to take steps that will make the service more "tangible" to potential customers, which can be reflected through promotional activities and materials as well as other details related to the service company, thereby also suggesting the model of market business. In this way, it creates the picture (i.e. image) of service organization, or the manner in which a person or group of users is experiencing it (Kotler et al., 2010).

The model of service quality, with the use of technical and functional dimensions, and the explanation of how they affect image building, as well as the total perceived quality of services provided by users/consumers, i.e. the difference between the expected and perceived service can also be used to explain what is called the "missing service quality concept" (Figure 2):

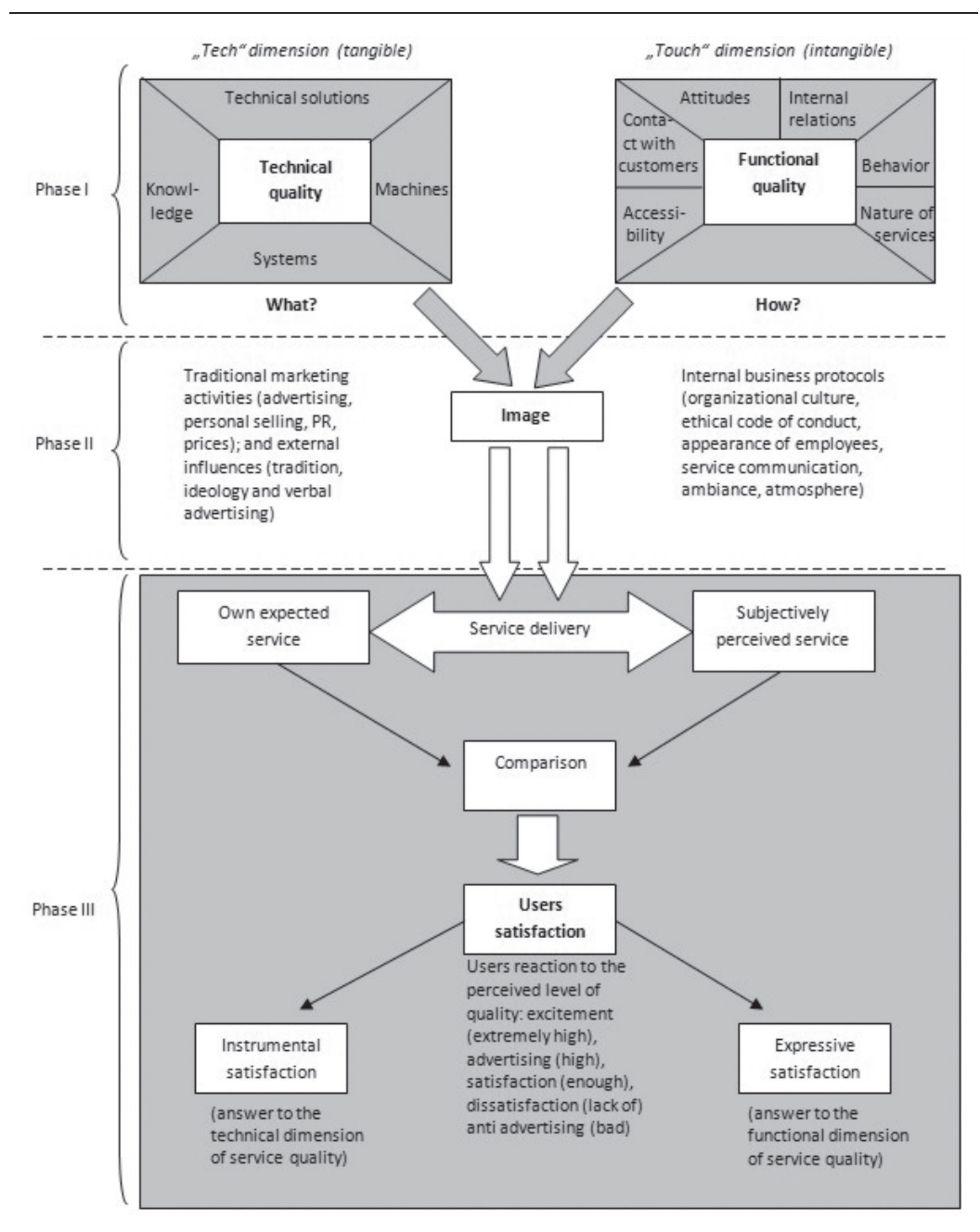

Figure 2. The integrated management model of service quality and customer satisfaction

Adapted from: Grönroos (1982, p. 79); Dreyer and Dehner (2003, p. 22); Witt and Moutinho (1995, pp. 207-213) 
A constructed model of service, along with the two dimensions of quality (tangible/"tech" or intangible/"touch") also identifies three main phases in the process of providing or using services, i.e. consumption cycle, including the following (Meyer and Westerbarkey, 1991):

1. Phase I $\rightarrow$ the "core-consumption" of service (quality of potentials);

- of provider - potential of the specifications and contacts,

- of consumers - potential of the integration and interactivity,

2. Phase II $\rightarrow$ the "consumption of the service" (process quality) - behavior in the process, and

3. Phase III $\rightarrow$ the "post-consumption of services" (quality of results) - the processual end result.

The process of converting the intangible into tangible can be viewed in the context that distinguishes two major groups of elements of tourism services (Table 1):

\begin{tabular}{|c|c|}
\hline \multicolumn{2}{|c|}{ TOURIST SERVICES } \\
\hline $\begin{array}{l}\text { Intangible elements } \\
\text { („,soft elements“) }\end{array}$ & $\begin{array}{l}\text { Tangible elements } \\
\text { („hard elements“) }\end{array}$ \\
\hline $\begin{array}{l}\text { - the relationship } \\
\text { between providers / } \\
\text { producers and users } \\
\text { (customers) } \\
\text { - reliability of staff/ } \\
\text { mentality } \\
\text { - personal attention } \\
\text { to the user/ } \\
\text { commitment } \\
\text { - courtesy/ } \\
\text { friendliness of staff } \\
\text { - service information }\end{array}$ & $\begin{array}{l}\text { - corporate image of } \\
\text { the company } \\
\text { - } \text { corporate logo } \\
\text { - marketing activities } \\
\text { - service atmosphere } \\
\text { / interior and } \\
\text { exterior service } \\
\text { facility } \\
\text { - } \text { service equipment }\end{array}$ \\
\hline
\end{tabular}

Table 1. The elements of tourist service

Adapted from the text: Ćosić (2007, pp. 20-21)

It is evident that intangible elements of services mainly relate to the internal characteristics of organizational operations (human factor), while tangible elements mainly relate to external attributes of service organization and manifest through its impact on the environment and the impressions of visitors or users.
The providers of tourism services can perform service delivery in three ways: through staff, physical environment and service process (Segal-Horn, 1993). One of the most important ways in which service organization can differentiate itself from the competition is through constant delivery of higher quality, for instance, through providing more skilled and more reliable staff together with superbly designed serving ambience and superior delivery process.

\section{SERVICE QUALITY IMPROVEMENT ON} A CUSTOM BASIS

The users/customers are the "input" resources for the majority of tourism companies and therefore it is very important to understand their expectations in terms of the activities undertaken in the area of creating quality market services. If it turns out that the company services are designed in such a manner to meet or even exceed expectations, customer satisfaction can easily develop into a further form of marketing through recommendations, or the state of "post-purchase intentions", which is of great importance for creating "customer images" for the consumed services quality (Dreyer and Dehner, 2003).

Heavy users who are looking for very specific and sophisticated services, are putting pressure on tourism businesses / organizations to create modern, innovative services. The response to these challenges often results in the improvement of the existing services, creating necessary conditions for competitive advantage (both at national and international level). Therefore, demanding users who encourage progress within the organization and creation of the existing services facilitate the delivery of the new market values, which further affect the realized quality (Johnston and Clark, 2001).

The differentiated elements of total services are evaluated on the basis of objective and subjective methods. While an objective measurement is based on technical standards, the subjective measurements rely on customer expectations and their perception of service (Ćosić, 2007).

Despite the principles of interactive marketing, by which experienced service largely depends on the quality of interaction between users and suppliers in the delivery of services, the problems that directly affect the client show up in a service organization. In order to accurately analyse this connection, that is, 
interaction between the factors of service processes and clients / as well as clients among themselves, a functional model of service system has been devel- oped (System of Servuction). This model also indicates some of the main features of tourism services (see Figure 3).

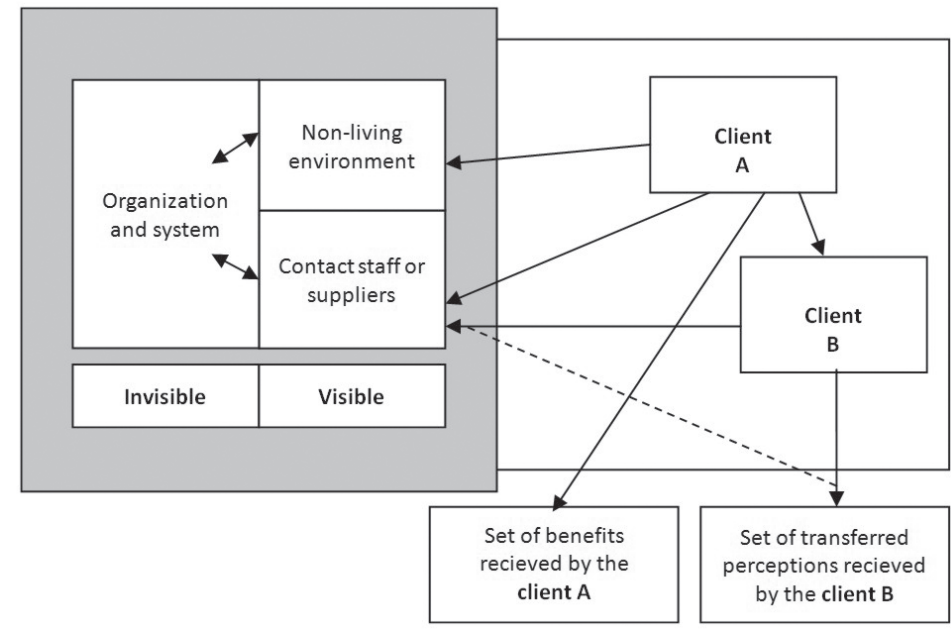

Figure 3. The model of functional system of tourist service Adapted from: Lageard et al. (1981, p. 134)

The model illustrates the inseparability of employees and customers from the service delivery system. Namely, they are completely equal service process factors. The arrow from client A to the contact personnel shows that contact staff will have a direct effect on satisfaction / perception of client A. This could be positive if the employee performs his duty well, or negative, if the employee works poorly. Regardless of the estimated perception value, it is as such directly transferred from the client A to other clients. In this way, client $\mathrm{B}$ already develops proper prejudices and attitudes concerning the quality. This can certainly make it more difficult and endanger the future communication and relationships with employees in service companies. Generally, this model shows the functional complexity of the delivery system of tourist services in a very simplified and precise way.
Pleasure/satisfaction is the result of an assessment (whether positive, neutral or negative) and assessment by user consumed services based on a comparison of their perceptions with their service expectations. Regarding that, three components should be distinguished when assessing the level of satisfaction: the so-called "need service" (expectations), the socalled "is service" (perception/experience) and the "need-is" comparison. In other words, the basic paradigm of establishing relationships with customers is the response of a tourist company concerning the situation or the event through which it is confirmed or not-confirmed whether there is a non-fulfillment and violation of expectations on which the degree of satisfaction directly depends (Ćosić, 2007).

The dominating factors which influence the outcome of user satisfaction, depending on the phase of service design, are shown in table (Table 2):

\begin{tabular}{cll}
\hline No. & PHASE NAME & \multicolumn{1}{c}{ FACTORS OF SATISFACTION } \\
\hline I & Fore-consumption & $\begin{array}{l}\text { mindset of the user } \\
\text { previous experience with the service } \\
\text { individual information about the service }\end{array}$ \\
\hline II & Consumption & $\bullet \begin{array}{l}\text { subjective impressions (reviews) of users } \\
\text { focus on quality }\end{array}$ \\
\hline Post-consumption & $\bullet \begin{array}{l}\text { focus on new experience and observations } \\
\text { (perceptions) }\end{array}$ \\
\hline
\end{tabular}

Table 2. Factors of satisfaction of tuorist service users by phases of the service process 
From the management perspective, the adapting forms of facilities and services of tourist companies require the business operations relating to the preparation and maintenance of the entire utility program. This provides a continuity of supervision over the market-supplied quality. In this respect, the successful preparation and maintenance of services, and therefore, the profitability of the whole business, is mainly determined by the following groups of elements and their relationships (Čačić, 2010):

1. User (guest) must be the starting and ending point of every business operation of tourism service company;

2. The hotel is a "second home" for the user where he expects to receive security of havens, pleasant and relaxed atmosphere, orderliness, warmth and other benefits;

3. Developing psychological / emotional-economic relations between the service company and its clients (subject should be appropriately built and equipped); and

4. Maintaining the service quality level.

Delivering a superior service value on a continuous basis to targeted users requires the evaluation of ability by relevant value makers and identifying factors that affect it. The starting assumption of the model is the enlargement of value for the customer as the most important condition for sustainable competitive advantage (Williams and Buswell, 2005). Delivering a superior service value in modern business conditions depends on few resources, i.e. service production means, and the ability of the organization to ensure their efficient and effective implementation (Stanković and Đukić, 2009). This application can be controlled with the use of models for the analysis and monitoring of production and the delivery service cycle.

The prediction and control of services provided, their scope and quality, are hampered primarily due to the intangibility of services, necessity of the user to be present at the place of service creation and inconsistency of employee behavior towards the user. It is also very difficult to establish quality standards in the labor-intensive personal services ("one-toone services"), while it is much easier to control the quality in the services based on the dominant use of the equipment and techniques ("equipment base services") because of the presence of tangible, material elements in production and delivery (Ćosić, 2007).

The construction and improvement of quality leads to a vision of the future, which is included in the strategic objectives of the service organization (Williams and Buswell, 2005). Regardless of which management system is associated with the quality rules implemented by the service organization, consideration is made only when there is a need to monitor the delivery of services and consider the consumer opinion in regard to the quality.

\section{CONCLUSIONS}

The importance of determining the appropriate level and dimension of the quality of tourism services is reflected in the creation of the basic preconditions for establishing strategic and effective marketing systems that are consistent with the possibilities of meeting and surpassing the needs of the users, while the achieved quality would be the only criterion, i.e. valid indicator of adaptation and market penetrating power of service companies.

The consistency and persistence in the implementation of organizational principles, and the application of corporate defined techniques and integrated management systems in achieving the quality (based on the user expectations according to the established levels and dimensions of the emerging service value) - together provide a continuity of existence, secure prosperity and potential affirmation of the finally achieved marketing placement (i.e. tourism services). The above stated confirms the usefulness of the given systematic approach, designed and implemented with the aim to improve management quality systems.

Therefore, there is a possibility of finding effective solutions to the problem presented in this paper related to the distribution of tourist services of coordinated and internally verified quality. This can be concluded by confirming the main research hypotheses (derived from the appointed introductory question), as follows: the process of creating the resulting values by reviewing the basic dimensions and efficiency of the production system can be directly related to the system of delivery of an appropriate tourism service and thus indicate its functional condition and maintenance of quality.

By using the data obtained from the structural analysis (i.e. integrated assessment) of production and delivery systems, a more meaningful organizational information base is formed, from which achieves an effect of uplift the ability of internal quality assurance and improvement of the organizational structure by establishing a stronger and more 
stable relationship between the factors of the service process, which further contributes to the perceived level of quality of tourism service, and leads to higher user satisfaction.

\section{REFERENCES}

Cooper, C., \& Hall, M. (2008). Contemporary Tourism: An International Approach. Oxford: ButterworthHeinemann.

Čačić, K. (2010). Poslovanje preduzeća u turizmu. Beograd: Univerzitet Singidunum. (in Serbian)

Čerović, S. (2009). Strategijski menadžment u turizmu. Beograd: Univerzitet Singidunum. (in Serbian)

Ćosić, M. (2007). Upravljanje kvalitetom turističkih usluga. Beograd: Visoka turistička škola. (in Serbian)

Dreyer, A., \& Dehner, C. (2003). Kundenzufriedenheit im Tourismus: Entstehung, Messing und Sicherung mit Beispielen aus der Hotelbranche. Oldenbourg: Lehr und Handbücher zum Tourismus, Verkehr und Freizeit. (in German)

Grönroos, C. (1982). Strategic Management and Marketing in Service Sector. Helsingfors, Finland: Swedish School of Economics and Business Administration.

Heleta, M. (2008). Menadžment kvaliteta. Beograd: Univerzitet Singidunum. (in Serbian)

Johnston, R., \& Clark, G. (2001). Service Operations Management. London: Prentice Hall.

Kosar, Lj. (2002). Hotelijerstvo: teorija i praksa. Beograd: Viša hotelijerska škola. (in Serbian)

Kosar, Lj., \& Rašeta, S. (2005). Izazovi kvaliteta: menadžment kvaliteta u hotelijerstvu. Beograd: Viša hotelijerska škola. (in Serbian)
Kotler, P., Bowen, J.T., \& Makens, J.C. (2010). Marketing u ugostiteljstvu, hotelijerstvu $i$ turizmu. Zagreb: MATE. (in Croatian)

Kotler, P., \& Keller, K.L. (2012). Marketing Management (14th ed.). New Jersey: Prentice Hall.

Langeard, E., Bateson, J., Lovelock, C., \& Eiglier, P. (1981). Marketing of services: New Insights from Customers and Managers. Report No. 81-104. Cambridge. MA: Marketing Science Institute.

Meyer, A., \& Westbarkey, P. (1991). Bedeutung der Kundenbeteiligung für die Qualitätspolitik von Dienstleistungsunternehmen.In: Bruhn, M., Stauss, B., ed. Dienstleistungsqualität: Koncepte-Methoden-Erfahrungen. (pp. 83-103). Wiesbaden: Gabler Verlag. (in German)

Müller, H. (2000). Qualitätsorientiertes Tourismus-Management. Bern: Paul Haupt. (in German)

Popesku, J. (2009). Marketing u turizmu. Beograd: Visoka turistička škola strukovnih studija. (in Serbian)

Segal-Horn, S. (1993). The internationalization of service firms. Advances in Strategic Management, 9, 31-55.

Seghezzi, H.D. (1992). Top Management and Quality. München: Hanser Publishers.

Stanković, Lj., \& Đukić, S. (2009). Marketing strategija orijentisana na vrednost. Marketing, 40(2), 73-78. (in Serbian)

Williams, Ch., \& Buswell, J. (2005). Service Quality in Leisure and Tourism. London: CABI Publishing.

Witt, S.F., \& Moutinho, L. (1995). Tourism Marketing and Management Handbook (2nd ed.). Hertfordshire, UK: Prentice-Hall.

Zeithaml, V.A., \& Bitner, M.J. (2003). Service Marketing: Integrating Customer Focus Across The Firm. New York: McGraw-Hill.

\section{STRUKTURNO-DIMENZIONALNI KONCEPT KVALITETA TURISTIČKIH USLUGA}

\section{Rezime:}

Teškoće isporučivanja konstantno zadovoljavajućeg kvaliteta turističke usluge nastaju kao posledica neusaglašenosti između proizvodnih struktura i odgovarajućih dimenzionih odlika isporučujućih vrednosti tokom konzumnog ciklusa. Za navedenu pojavu odgovoran je pre svega organizacioni sistem preduzeća, sačinjen od proizvodnih (radnih) jedinica i službi zaduženih za upravljanje kvalitetom, kao i kontrolu i nadgledanje procesa proizvodnje, odnosno toka isporuke. Ovaj rad razmatra aktuelne modele strukturne kompleksnosti, dimenzionog sagledavanja kvaliteta, kao i faze učešća korisnika tokom životnog ciklusa turističke usluge. Mogućnost izdvajanja nekoliko karakterističnih nivoa složenog turističkog produkta obezbeđuje uporište za sadržajnije poređenje na relaciji „projektovani i ostvareni kvalitet" i postizanje većih organizacionih performansi u domenu tržišno isporučene vrednosti rezultujuće usluge. Glavni cilj rada je pružiti teorijsku osnovu za primenu dubljih organizaciono-funkcionalnih modela analize i kontinuirano praćenje postignutog kvaliteta. Efekat ovakvog sistemskog pristupa manifestovao bi se na konačni stepen ispunjavanja očekivanja i ukupno zadovoljsvo potrošača (ili korisnika) turističkom uslugom.

\section{Ključne reči:}

turističke usluge, strukturni koncept, dimenzionalni modeli, kvalitet.

Received: July 27th, 2013.

Correction: September 25th, 2013.

Accepted: September 26th, 2013. 